\title{
EFFECT OF TEMPERATURE AND AIR-GAP WIDTH ON THE DESALINATION EFFICIENCY OF AIR-GAP MEMBRANE DISTILLATION MODULE
}

\author{
Le Thanh Son*, Nguyen Tran Dung, Nguyen Tran Dien \\ Institute of Environmental Technology - Vietnam Academy of Science and Technology
}

\section{ABSTRACT}

Seawater desalination is a promising solution that can be applied to solve the problem of scarcity of freshwater and clean water in Vietnam, especially in islands and remote areas. Recently, the application of membrane distillation techniques for desalination has been attracting the attention of many scientists because of its simplicity, ease of operation and energy saving. An air-gap membrane distillation (AGMD) module was created on the basis of a low-density PE membrane with $12 \times 5 \mathrm{~cm}$ size, porosity, width and average hole size was $85 \%, 76 \mu \mathrm{m}$, and $0.3 \mu \mathrm{m}$ respectively. The width of the air space was controlled by the change in the number of plastic mesh in the permeability chamber. The results showed that the quality of permeate solution was identical with the quality of normal distillate water and the desalination efficiency of AGMD module strongly depended on the feed temperature, air-gap. The optimum condition found was $60^{\circ} \mathrm{C}$ of feed temperature and air-gap width of $5 \mathrm{~mm}$, then the water recovery flux reached $2.5 \mathrm{~L} \cdot \mathrm{m}^{-2} \cdot \mathrm{h}^{-1}$.

Keywords: Desalination; freshwater; seawater; water recovery; membrane distillation; AGMD

Received: 26/11/2019; Revised: 14/02/2020; Published: 18/02/2020

\section{ẢNH HƯởNG CỦA NHIẸT Độ VÀ CHIỀU DÀY CỦA LỚP ĐỆM KHÍ ĐẾN HIỆU QUẢ KHỬ MậN CỦA MÔ-ĐUN CHƯNG CẤT MẦNG ĐỆM KHIÍ}

\author{
Lê Thanh Sơn*, Nguyễn Trần Dũng, Nguyễn Trần Điện \\ Viện Công nghệ môi trương - Viện Hàn lâm Khoa học Công nghệ Việt Nam
}

\section{TÓM TẮT}

Khử mặn nước biển là một giải pháp đầy hứa hẹn có thể được áp dụng để giải quyết vấn đề khan hiếm nước ngọt và nước sạch ở Việt Nam, đặc biệt là ở các vùng hải đảo và vùng sâu vùng xa. Gần đây, việc áp dụng các kỹ thuật chưng cất màng để khử mặn đang thu hút sự chú ý của nhiều nhà khoa học vì tính đơn giản, dễ vận hành và tiết kiệm năng lượng. Một mô-đun chưng cất màng đệm khí (AGMD) đã được chế tạo trên cơ sở màng PE mật độ thấp với kích thước $12 \times 5 \mathrm{~cm}$, độ xốp, chiều dày và kích thước lỗ trung bình lần lượt là là $85 \%, 76 \mu \mathrm{m}$, và $0,3 \mu \mathrm{m}$. Chiều dày của lớp đệm khí được kiểm soát bởi sự thay đổi số lượng tấm lưới nhựa trong buồng thấm. Kết quả thu được cho thấy chất lượng của dung dịch thấm qua màng tương đương với chất lượng của nước cất và nhiệt độ dòng cấp, chiều dày của lớp đệm khí ảnh hưởng mạnh đển hiệu quả khử mặn của môđun AGMD. Điều kiện tối ưu được tìm thấy là nhiệt độ dòng cấp là $60^{\circ} \mathrm{C}$, chiều dày của lớp đệm khí là $5 \mathrm{~mm}$, khi đó thông lượng thu hồi nước đạt $2,5 \mathrm{~L} \cdot \mathrm{m}^{-2} \cdot \mathrm{h}^{-1}$.

Từ khóa: Khử mặn; nước ngọt; nước biển; thu hồi nước; chung cất bằng màng; chung cất màng đệm khí.

Ngày nhận bài: 26/11/2019; Ngày hoàn thiện: 14/02/2020; Ngày đăng: 18/02/2020

* Corresponding author. Email: thanhson96.le@gmail.com

https://doi.org/10.34238/tnu-jst.2020.02.2354 


\section{Introduction}

Water is an essential thing for human being and almost living organism in the world. An adequate supply of clean water, both with quality and quantity, is always a challenge for developing countries such as Vietnam. According to UN, more than 1 billion people in the world are unable to access clean water and 2.6 billion people are using water without proper sanitation [1]. The rapid increase of population, accompanied by the lack of infrastructure and financial supply makes access to clean water in the rural areas of Vietnam more difficult. According to different reports, less than half of the Vietnamese population has access to clean water and sanitation [2], while the rest of Vietnamese population in rural areas and remote areas have to use groundwater sources (drilled wells) and rainwater to overcome the water scarcity [3]. The use of groundwater is risky because according to Luu [4], groundwater sources in rural areas in Vietnam are not safe enough to drink when heavy metal concentrations such as $\mathrm{As}, \mathrm{Fe}$, and $\mathrm{Mn}$ exceed the WHO regulations for drinking water. Harvesting rainwater to replace groundwater and surface water is also an effective, simple and suitable solution for rural and remote areas in Vietnam. But this is not a proper solution when the amount of rainwater strongly depends on the climate. Relying on rainwater as the main source of water is not sufficient, especially in the dry season. Lee et al. reported that the rainwater in Vietnam is non-toxic but E.coli and Coliforms bacteria will appear if the rainwater is not treated with UV light [5]. This is challenging because purchasing UV lamps for installation in rural areas is quite difficult due to the expensive price and poorly experience.

Seawater desalination is an appropriate solution that can be applied to solve the problem of scarcity of freshwater and clean water in rural and remote areas in Vietnam. In many countries around the world, water supply plants with traditional heat desalination or reverse osmosis technology are applied on a large scale to extract fresh water from seawater [6], typically in Spain and Israel. Traditional thermal distillation processes include boiling, multi-stage flash (MSF), multiple-effect distillation (MED), vapor compression (VC). A common feature of these processes is that they all consume a lot of energy due to the use of heat to boil water to a certain temperature for desalination [7]. In RO, the osmotic pressure is overcome by using an external pressure higher than the osmotic pressure on the seawater; hence, water flows in the reverse direction to the natural flow across the membrane, while the dissolved salt is left behind at the surface of the membrane. One of the advantages of this technology is it does not require energy to heat the water but high pressure applied during the extraction process, which means all the components and equipment must be designed by using expensive, non-corrosive stainless material. Furthermore, during the process, dissolved salts are retained on the membrane surface and clog the membrane, which causes a reduction in the water flux or an increase in the pressure required for the process. To prevent and monitor the clogging of the membrane surface, this requires pretreatment of the influent by different processes, accompanied by membrane cleaning frequently [8].

In the current situation, the Membrane Distillation (MD) technology can be a very promising solution. The MD process is a combination of traditional heat distillation and membrane separation, which uses hydrophobic microfiltration membranes, meaning that only water vapor exits and the salts dissolved in water and other compounds will be retained in the membrane surface [8]. The difference in temperature between the two sides of the membrane creates a steam pressure gradient - the driving force for mass transfer (steam moves through the filter). 
There are four main types of distillation filter system properties: air-gap membrane distillation (AGMD), direct contact membrane distillation (DCMD), sweeping gas membrane distillation (SGMD) and vacuum membrane distillation (VMD) (Fig. 1). DCMD has the ability to use higher flow rates, but this type of MD has the disadvantage that the permeate solution output will go along with the cooler solution so it is not possible to separate the permeate solution. For SGMD and VMD, complicated equipment and tools are used to construct the system; these two types of membrane construction also require an additional cooling device (steam) and a steam condensation unit to collect permeate solution. Besides, it is necessary to use energy for the pump to collect the steam flow from the cold chamber of the membrane system. AGMD improves the disadvantage of DCMD by separating effluent to obtain permeate solution. There is also no need for additional equipment to collect water vapor and condensation as SGMD and VMD. As a result, AGMD system is applied in large scale fresh water supply factories in United Arab Emirates (UAE) with a capacity of $80 \sim 100$ $\mathrm{m}^{3}$. day ${ }^{-1}[9]$.

In this study, saline water is desalinated by a laboratory scale AGMD system, in which the influence of some factors such as feed solution temperature and air-gap width have been investigated.

\section{Material and Methods}

\subsection{The lab-scale AGMD system}

In the AGMD module shown in Fig 1, each acrylic mold is engraved to form a shallow groove of depth, width, length of $0.3,5,8 \mathrm{~cm}$ respectively to place the membrane and pads, grids, condensing plates. The experiment uses a low-density PE membrane imported from the laboratory of the Faculty of Engineering and Information Science, Wollongong
University, Australia with the porosity, width, and average hole size of the corresponding PE membrane is $85 \%, 76 \mu \mathrm{m}$, and $0.3 \mu \mathrm{m}$. The gasket works to seal and create air space. The plastic mesh in the permeability chamber maintains the width of the air space and allows condensed water evaporation flow easily.

In the hot phase, synthetic seawater from the feed container was heated to the desired temperature (kept at $60^{\circ} \mathrm{C}$ for all experiments except the phase about effect of feed solution temperature) and pumped into the membrane module by a pumping system. Inside the feed container, a temperature sensor was placed to control the temperature of the feed solution. In the cool phase, distilled water was used as a cool solution; the temperature was kept at $25^{\circ} \mathrm{C}$. The cool solution was pumped into the cool side of the module to help the water steam condensed quickly.

Synthetic saltwater or $\mathrm{NaCl}$ solution of 35 g. $L^{-1}$ was used as feed solution for all experiments except the phase about effect of salt concentration in the study. To overcome the fouling problem, before operating an experiment, the membrane module was washed by using distilled water for an hour to temporally clean the membrane surface, avoid the clogging and fouling.

\subsection{Experimental protocols}

The experiences were conducted at the Institute of Environmental Technology in order to study the impact of feed solution temperature and air-gap width on the distillation efficiency of the AGMD module. The constant recovery mode was selected in this study, which means the volume of feed solution did not change through times, resulting in aconstant salt concentration. The water recovery in the concentrating mode is defined as the water flux of the system:

$$
I=\frac{\left.\Delta V_{\text {distillato }} 1\right)}{s \Delta t}
$$

where $\mathrm{J}$ is the water flux $\left(\mathrm{L} \cdot \mathrm{m}^{-2} \cdot \mathrm{h}^{-1}\right), \Delta \mathrm{V}_{\text {distillate }}$ (L) is the volume of distillate water obtained 
at the end of the experiment, $\mathrm{S}$ is the surface area of the membrane $\left(\mathrm{m}^{2}\right)$ and $\Delta \mathrm{t}(\mathrm{h})$ is the operation time.

The experimental process was separated into 2 phases to evaluate the effects of feed solution temperature and the air-gap width. In fact, the concentration of feed solution is considered as factor altering the distillation process but the salt concentration in feed solution has an insignificant impact on the permeate flux at high feed flow rates due to high turbulent levels achieved at higher flow rates, which lessen the effects of the concentration polarization [10]. Furthermore, the flow rate does not have much impact on the efficiency of the system [11]. For both phases, operation time was 3 hours per experiment. During the experiment, TDS, $\mathrm{pH}$, and conductivity were measured for both influent and effluent to evaluate the performance of the module.

\subsection{Materials and analysis}

Sodium chloride (99.5\%, Merck) was used for preparation of synthetic saltwater.

During the study, the measurement of $\mathrm{pH}$, electrical conductivity (EC), total dissolved solid (TDS) were taken with a HANNA HI 9812-5 Portable $\mathrm{pH} / \mathrm{EC} / \mathrm{TDS} /{ }^{\circ} \mathrm{C}$ Meters along with HI1285-5 pH/EC/TDS Multiparameter Probe. Before testing, the probe was calibrated following the procedures. Samples were measured at the beginning and the end of the experiment. To evaluate the salt rejection efficiency of AGMD module, different ions were considered. The analysis of cation $\mathrm{Ca}^{2+}, \mathrm{Mg}^{2+}, \mathrm{Na}^{+}$and $\mathrm{K}^{+}$in the feed solution and permeate solution was followed TCVN: 6660:2000 (ISO 14911-1998). For anion $\mathrm{Cl}^{-}$and $\mathrm{SO}_{4}{ }^{2-}$, TCVN 6494:1999 was chosen to examine the influent and effluent, while $\mathrm{HCO}_{3}^{-}$was determined by Method 2320B in SMEWW 2005. The chemicals used for analysis of these ions were pure.

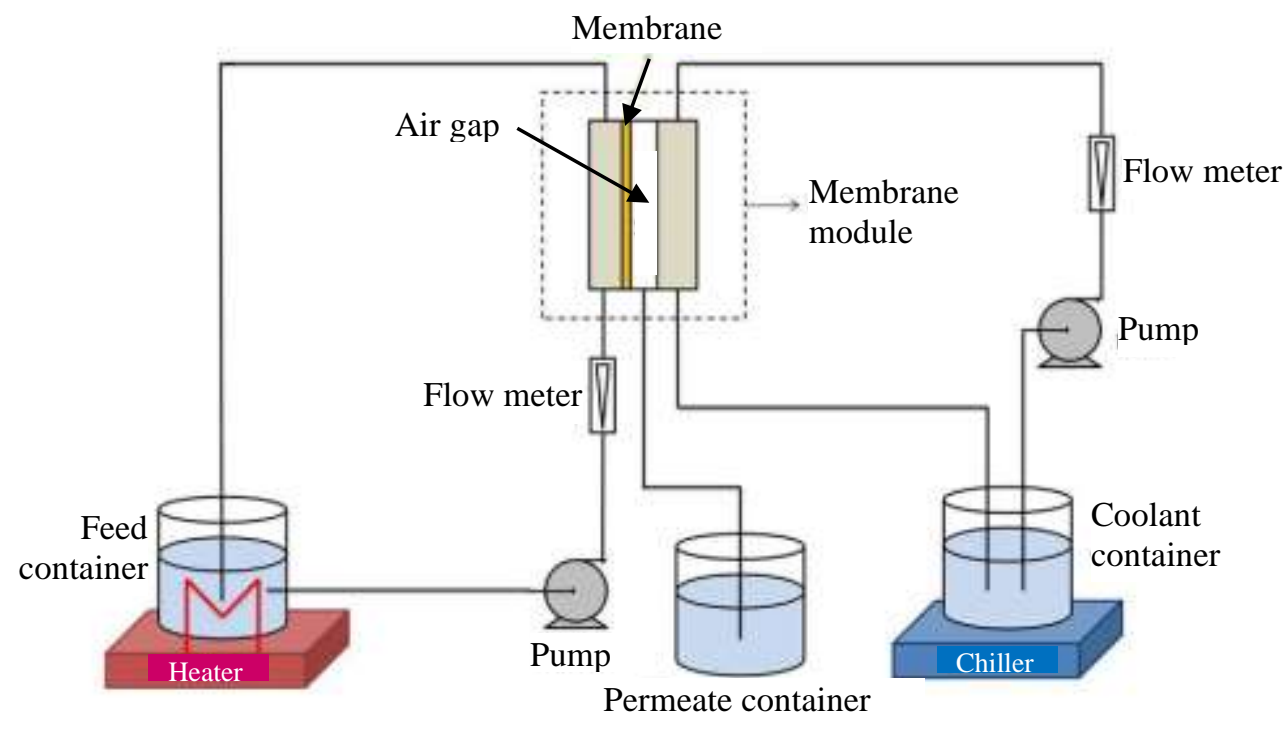

Figure 1. Scheme of the lab-scale AGMD system

\section{Results and discussion}

\subsection{Quality of permeate solution}

The preliminary assessment test for the permeate solution quality of the AGMD system conducted when the synthetic seawater solution ran through the AGMD system arranged as shown in Fig.1. The cool phase temperature was maintained at $20-25^{\circ} \mathrm{C}$, the temperature of feed solution was maintained at $60^{\circ} \mathrm{C}$ while the flowrate was 1 L.min ${ }^{-1}$. After 3 hours of operation, 
permeate solution was collected and analysed followed different parameters: TDS, $\mathrm{Ca}^{2+}, \mathrm{Mg}^{2+}$, $\mathrm{SO}_{4}^{2-}, \mathrm{Na}^{+}, \mathrm{Cl}^{-}, \mathrm{K}^{+}, \mathrm{HCO}_{3}{ }^{-}$. The analytical results compared with distilled water are shown in Table 1.

From the data, the quality of permeate solution was identical with the quality of normal distillate water, which means the distillation of AGMD was approximately $100 \%$ so it is not possible to rely on the value of permeate solution to evaluate the influence of factors on the membrane distillation process by AGMD system. Therefore, the efficiency of AGMD was calculated by recovery factor in equation (1).

Table 1. Quality of feed solution and permeate compared with distilled water

\begin{tabular}{ccccc}
\hline Parameter & Unit & Feed solution & Permeate solution & Distilled water \\
\hline $\mathrm{TDS}$ & $\mathrm{ppm}$ & 35000 & 3 & $\leq 3$ \\
$\mathrm{Ca}^{2+}$ & $\mathrm{mg} / 1$ & 0,18 & Not detected & Not detected \\
$\mathrm{Mg}^{2+}$ & $\mathrm{mg} / \mathrm{l}$ & 0,56 & Not detected & Not detected \\
$\mathrm{SO}_{4}^{2-}$ & $\mathrm{mg} / \mathrm{l}$ & 1,16 & Not detected & Not detected \\
$\mathrm{Na}^{+}$ & $\mathrm{mg} / \mathrm{l}$ & 4,59 & Not detected & Not detected \\
$\mathrm{Cl}^{-}$ & $\mathrm{mg} / 1$ & 8,25 & Not detected & Not detected \\
$\mathrm{K}^{+}$ & $\mathrm{mg} / \mathrm{l}$ & 0,17 & Not detected & Not detected \\
$\mathrm{HCO}_{3}{ }^{-}$ & $\mathrm{mg} / 1$ & 0,07 & Not detected & Not detected \\
\hline
\end{tabular}

\subsection{Effects of feed solution temperature}

The experiment was for evaluating the effects of temperature in hot phase of the AGMD designed as in Fig.1 with the parameters: the feed flow rate was $1.5 \mathrm{~L} \cdot \mathrm{min}^{-1}$, the feed temperature varies from 40 to $80{ }^{\circ} \mathrm{C}$, the cool phase temperature was maintained at $25^{\circ} \mathrm{C}$, the air-gap widthwas $5 \mathrm{~mm}$. Results were presented in Fig.2.

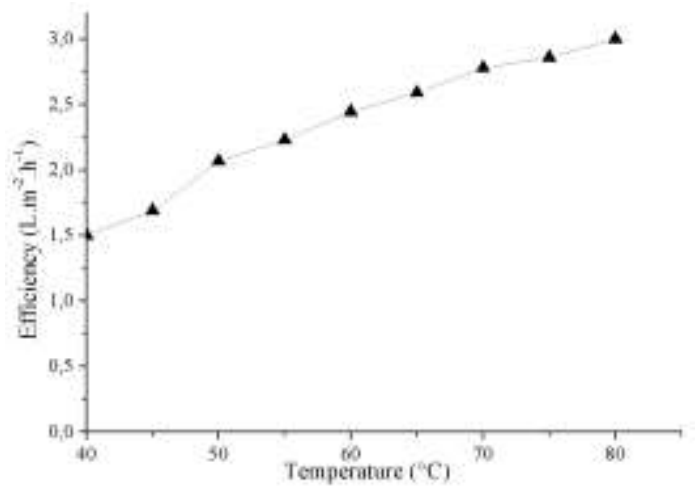

Figure 2. Performance of $A G M D$ in different temperature

As shown in Fig.2, the distillation efficiency of AGMD system dramatically depended on the temperature of feed solution. At higher temperature, recovery rate was higher, also for the water flux. This can be explained by using Antoine equation due to the relationship between vapor pressure and temperature [12].
An increase in temperature triggers an increase in the vapor pressure at the surface of membrane also, which aids the water passing speed through the membrane. On the other hand, the increasing temperature of feed solution also increased the temperature polarization effect and concentration polarization [13]. Moreover, the increment of temperature also led to other problems: heatresisted material, energy consumed or aiding the precipitation of dissolved salt $(\mathrm{NaCl})$ by the formation of water evaporation [14]. Therefore, the temperature of feed solution should be maintained at $60 \sim 70{ }^{\circ} \mathrm{C}$, which is also suitable for sustainable energy sources (solar energy) or excessive heat (from diesel engine of ships).

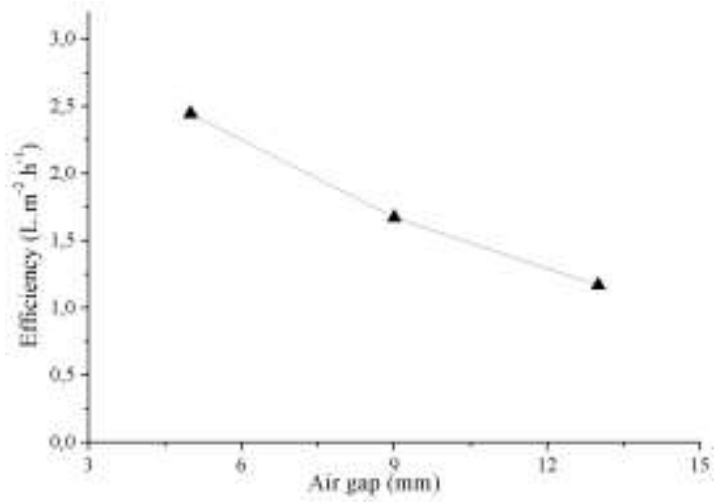

Figure 3. Performance of AGMD module with various air-gap width 


\subsection{Effects of air-gap width}

The experiment to assess effect of air-gap width on the performance of AGMD was executed with 3 different value: $5 \mathrm{~mm}, 9 \mathrm{~mm}$ and $13 \mathrm{~mm}$. Feed solution concentration was $35 \mathrm{~g} . \mathrm{L}^{-1}$ and operating temperature was at 60 ${ }^{\circ} \mathrm{C}$. Results were shown in Fig.3.

From the Fig.3, the efficiency of AGMD system decreased when the air-gap width increased. This can be explained by the influence of air-gap width to the heat transfer and mass transfer. For instance, the airgapwidth is inversely proportional to the water flux. A decreasing in the gap width would increase the temperature gradient within the gap compartment, while the distance that the evaporation water has to transport is reduced; both of these lead to an increment of the permeate flux. However, a higher gap width may decrease the heat loss by conduction through the membrane. This results in a thermal efficiency for the module but a higher mass transfer resistance is also presented [15]. Thus, considering the thermal efficiency and mass transfer resistance, the optimal air-gap width of $5 \mathrm{~mm}$ was chosen for further researches.

\section{Conclusion}

The results obtained from this study showed the relationship between temperature of feed solution, feed flow rate, concentration of salt and air-gap width to the distillation efficiency of AGMD module to extract synthetic seawater. The study proved that the quality of permeate solution was identical with the quality of normal distillate water. With feed temperature of $60{ }^{\circ} \mathrm{C}$ and air-gap width of $5 \mathrm{~mm}$, the optimal configuration of AGMD module was evaluated and used for further researches to examine the applicability of AGMD modules for desalination in Vietnam.

\section{Acknowledgements}

This work is supported by the selected grassroots level scientific research project in
2019 of the Institute of Environmental Technology "Study using distillation membrane technology to desalinate seawater and evaluate applicability in Vietnam".

\section{REFERENCES}

[1]. United Nation Development Program (UNDP), Human Development Report 2006, 2006.

[2]. World Bank group, Water Supply and Sanitation in Vietnam, 2014.

[3]. S. Ozdemir, M. A. Elliott, and J. Brown, "Rainwater Harvesting Practices and Attitudes in the Mekong Delta of Vietnam," J. Water. Saint. Hyg. De., vol. 1(3), pp. 171-177, 2011.

[4]. T. Luu, "Remarks on the current quality of groundwater in Vietnam," Environ. Sci. Pollut. Res. Int., vol. 26, pp. 1163-1169, 2019.

[5]. M. Lee, M. Kim, Y. Kim, and M. Han, "Consideration of rainwater quality parameters for drinking purposes: A case study in rural Vietnam," J. Environ. Manage., vol. 200, pp. 400-406, 2017.

[6]. M. Elimelech and W. A. Phillip, "The Future of Seawater and the Environment," Science. vol. 333, pp. 712-718, 2011.

[7]. Y. Ghalavand, M. S. Hatamipour and A. Rahimi, "A review on energy consumption of desalination processes," Desalin. Water. Treat., vol. 54 (6), pp. 1626-1541, 2014.

[8]. H. C. Duong, N. D. Phan, T. V. Nguyen, T. M. Pham, and N. C. Nguyen, "Membrane distillation for seawater desalination applications in Vietnam: potential and challenges," Vietnam Journal of Science and Technology, vol. 55(56), pp. 659-682, 2017.

[9]. B. B. Ashoor, A. Giwa and S. W. Hasan, "Full-Scale Membrane Distillation Systems and Performance Improvement Through Modeling: A Review" in Current Trends and Future Developments on (Bio-) Membranes. Membrane Desalination Systems: the Next Generation, A. Basile, E. Curcio, Inamuddin, Eds. Elsevier, 2018, pp. 105-133.

[10]. A. Khalifa, D. Lawal, M. Antar, and M. Khayet, "Experimental and theoretical investigation on water desalination using air gap membrane distillation," Desalination, vol. 376(16), pp. 94-108, 2015. 
[11]. R. Bahar, M. N. A. Hawlader and T. F. Ariff, "Channeled coolant plate: A new method to enhance freshwater production from an air gap membrane distillation (AGMD) desalination unit," Desalination, vol. 359(2), pp. 71-81, 2015.

[12]. M. Khayet, "Membranes and theoretical modeling of membrane distillation: A review," Adv. Coll. Interf. Sci., vol. 164, pp. 56-88, 2011.

[13]. B. R. Babu, N. K. Rastogi and K. S. M. S. Raghavarao, "Concentration and temperature polarization effects during osmotic membrane distillation," J. Membrane. Sci., vol. 322(1), pp.146-153, 2008.

[14]. C. U. I. Guodong et al., "Formation water evaporation induced salt precipitation and its effect on gas production in high temperature natural gas reservoirs," Petrol. Explor. Dev, vol. 43(5), pp. 815-824, 2016.

[15]. J. A. Sanmartino, M. Khayet, and M.C. Garcia-Payo, "Desalination by Membrane Distillation" in Emerging Membrane Technology for Sustainable Water Treatment, R. Singh, N. Hankins, Eds. Elsevier, 2016, pp. 77-110. 